\title{
ANALISIS PENGARUH KUALITAS PRODUK, PELAYANAN DAN LOKASI TERHADAP KEPUASAN PENGUNJUNG WARUNG KOPI ONE LOVE DI KOTA KUALA SIMPANG
}

\author{
Oleh \\ Thursina Mahyuddin, S.Sos, MSP1/Juraidah² \\ ${ }^{1}$ Dosen Tetap Program Studi Agribisnis Fakultas Pertanian \\ ${ }^{2}$ Mahasiswa Fakultas Pertanian Program Studi Agribisnis \\ Universitas Samudra, Langsa-Aceh
}

\section{Ringkasan}

Analisis Pengaruh Kualitas Produk, Pelayanan dan Lokasi Terhadap Kepuasan Pengunjung Warung Kopi One Love di Kota Kuala Simpang. Penelitian ini bertujuan untuk mengetahui pengaruh kualitas produk, kualitas layanan dan lokasi terhadap kepuasan pengunjung warung kopi One Love di Kota Kuala Simpang. Metode penelitian yang digunakan dalam penelitian ini adalah metode survey. Penentuan daerah sampel dilakukan secara Sampling kuota adalah teknik untuk menentukan sampel dan populasi yang mempunyai ciri-ciri tertentu sampai jumlah (kuota) yang diinginkan. Berdasarkan metode tersebut jumlah sampel yang diambil dalam penelitian ini adalah sebanyak 33 orang.

Berdasarkan hasil perhitungan analisis regresi linear berganda maka diperoleh persamaan regresi sebagai berikut : $Y=1,57+0,44 X_{1}+0,42 X_{2}+0,19 X_{3}$. Dari hasil Nilai koefisien determinansi $\left(R^{2}\right)$ sebesar 0,99 atau $99 \%$ artinya analisis kepuasan pengunjung warung kopi One love dipengaruhi oleh kualitas produk $\left(\mathrm{X}_{1}\right)$, kualitas layanan $\left(\mathrm{X}_{2}\right)$ dan lokasi $\left(\mathrm{X}_{3}\right)$ di Kota Kuala Simpang. Sedangkan 1 \% lagi dipengaruhi oleh faktor-faktor lain diluar variabel penelitian yang tidak dihitung nilainya.

Hasil pengujian secara serempak (Uji F) diperoleh $F_{\text {hitung }}=1.010,66>F_{\text {Tabel }}=1,97$ pada tingkat kepercayaan $95 \%(\alpha=0,05)$ dan juga $F_{\text {hitung }}=1.010,66>F_{\text {Tabel }}=4,59$ pada tingkat kepercayaan $99 \%(\alpha=$ 0,01 ), sehingga dapat diambil kesimpulan bahwa secara serempak atau bersama-sama variabel kualitas produk $\left(X_{1}\right)$, kualitas layanan $\left(X_{2}\right)$ dan lokasi $\left(X_{3}\right)$ secara keseluruhan memberi pengaruh yang sangat nyata terhadap kepuasan pengunjung warung kopi one love di Kuala Simpang.

Hasil pengujian secara parsial atau secara terpisah pada tingkat kepercayaan $95 \%(\alpha=0,05)$ untuk variabel kualitas produk $\left(X_{1}\right)$, kualitas layanan $\left(X_{2}\right)$ dan lokasi $\left(X_{3}\right)$ dapat dilihat bahwa $t_{1}$ cari $=24,46$, dan $t_{3}$ cari $=$ $6,55>t_{\text {tabel }}=1,6991$ pada tingkat kepercayaan 95\% $(\alpha=0,05)$ dan $>$ tabel $=2,4620$ pada tingkat kepercayaan $99 \%(\alpha=0,01)$. $t_{2}$ cari $=1,35<t_{\text {tabel }}=1,6991$ pada tingkat kepercayaan $95 \%(\alpha=0,05)$ dan $<$ tabel $=2,4620$ pada tingkat kepercayaan $99 \%(\alpha=0,01)$. Sehingga diambil kesimpulan bahwa secara terpisah variabel kualitas produk $\left(\mathrm{X}_{1}\right)$ dan lokasi $\left(\mathrm{X}_{3}\right)$ secara keseluruhan memberi pengaruh yang sangat nyata terhadap kepuasan pengunjung warung kopi one love, sedangkan kualitas layanan $\left(\mathrm{X}_{2}\right)$ tidak memberi pengaruh nyata terhadap kepuasan pengunjung warung kopi one love di Kota Kuala Simpang.

Kata Kunci: Kualitas, Produk, Pelayanan, Lokasi, Kepuasan, Konsumen

\section{PENDAHULUAN}

\section{Latar belakang}

Indonesia merupakan negara agraris yang memiliki potensi besar dalam produksi komoditi yang bersumber dari kekayaan alam, termasuk sektor pertanian baik pangan maupun non pangan. sebagai negara pertanian, pertumbuhan ekonomi nasional Indonesia dipengaruhi oleh pertumbuhan sektor pertanian dimana peran sektor pertanian lebih tinggi dibandingkan beberapa sektor lainnya. Pertumbuhan sektor pertanian ini merupakan prestasi yang sangat baik bagi Indonesia.

Perkebunan merupakan salah satu subsektor pertanian yang memegang peranan penting dalam perekonomian nasional. Salah satu komoditas potensial hasil perkebunan yang berpengaruh terhadap perekonomian Indonesia adalah kopi. Kopi menjadi komoditas yang potensial untuk dikembangkan karena terjadi peningkatan kebutuhan terhadap kopi baik di dalam maupun luar negeri.

Sebagai komoditas yang potensial, kopi banyak digunakan sebagai bahan baku produk olahan oleh usaha kecil, menengah dan besar. Kebutuhan usaha terhadap bahan baku kopi dan kebutuhan konsumsi masyarakat yang selalu meningkat mengakibatkan petani kopi meningkatkan produksi sehingga produksi kopi nasional juga mengalami peningkatan setiap tahunnya. Untuk mengetahui peningkatan kopi setiap tahunnya mulai dari tahun 2004 sampai dengan tahun 2012 dapat dilihat pada tabel I-1 berikut : 
Tabel I-1 Produksi Kopi Nasional Tahun 2004-2014

\begin{tabular}{|c|c|c|c|}
\hline No & Tahun & $\begin{array}{l}\text { Jumlah Produksi } \\
\text { (Ton) }\end{array}$ & Pertumbuhan (\%) \\
\hline 1 & 2004 & 554.574 & 4,30 \\
\hline 2 & 2005 & 569.234 & 2,64 \\
\hline 3 & 2006 & 682.019 & 19,81 \\
\hline 4 & 2007 & 671.255 & 1,57 \\
\hline 5 & 2008 & 647.386 & 3,55 \\
\hline 6 & 2009 & 640.365 & 1,08 \\
\hline 7 & 2010 & 682.158 & 6,52 \\
\hline 8 & 2011 & 686.763 & 0,67 \\
\hline 9 & 2012 & 687.450 & 0,10 \\
\hline 10 & 2013 & 601.000 & 0,40 \\
\hline 11 & 2014 & 670.000 & 1,97 \\
\hline \multicolumn{2}{|c|}{ Rata-rata } & 644.745 & 3,87 \\
\hline
\end{tabular}

Sumber : Anonimous, (2012:3)

Dari tabel I-1 memperlihatkan bahwa rata-rata jumlah produksi kopi nasional dari tahun 2004-2014 ialah mencapai 644.745 ton dengan persentase pertumbuhan $3,87 \%$. Produksi tertinggi terlihat pada tahun 2012 yaitu sebesar 687.450 ton dengan pertumbuhan persentase 0,10 \%, sedangkan produksi terendah pada tahun 2004 yaitu sebesar 554.574 ton dengan persentase pertumbuhan 4,30\%.

Tabel I-2 Konsumsi Kopi Olahan Nasional Tahun 2002-2006

\begin{tabular}{|l|l|l|l|}
\hline No & Tahun & Jumlah (Ton) & Pertumbuhan (\%) \\
\hline 1 & 2002 & 120.000 & - \\
2 & 2003 & 109.980 & 8,35 \\
3 & 2004 & 120.000 & 8,35 \\
4 & 2005 & 150.000 & 25,00 \\
5 & 2006 & 170.000 & 13,33 \\
\hline
\end{tabular}

Sumber : ICO Coffee Statistic dan Asosiasi Eksportir Kopi Indonesia (AEKI) dalam Direktorat Jendral Perkebunan, (2007:10)

Dengan meningkatnya konsumsi kopi dari tahun ketahun dan perubahan gaya hidup masyarakat mengakibatkan berkembangnya industri warung kopi di Indonesia. Perkembangan warung kopi modern ini dapat terlihat dipusat-pusat perkotaan karena penduduk perkotaan memiliki
Kopi sebagai bahan minuman sudah tidak asing lagi. Kopi banyak digemari oleh berbagai kalangan masyarakat. Penggemarnya bukan saja bangsa Indonesia, tetapi juga berbagai bangsa di seluruh dunia. Dengan kandungan kafein yang punya rangsangan terhadap peningkatan kinerja beberapa bagian susunan saraf pusat.

Di Indonesia, kopi menjadi komoditas perkebunan yang sangat digemari oleh penduduk. Hal tersebut dapat dilihat dari peningkatan konsumsi kopi di Indonesia secara keseluruhan. Berdasarkan informasi yang didapat dari International Coffee Organization (ICO), Coffee Statistic dan Asosiasi Eksportir Kopi Indonesia (AEKI), Secara keseluruhan konsumsi kopi di dalam negeri mengalami peningkatan yang tinggi. Sebagian besar kopi yang dikonsumsi masyarakat adalah kopi yang telah diolah dan siap untuk dikonsumsi. Kopi olahan dapat berupa kopi dalam kemasan, kopi dalam gelas plastik dan produk olahan kopi lainnya. Peningkatan jumlah konsumsi kopi dapat dilihat pada tabel I-2 .

Tabel I-3 : Komposisi Kimia, Vitamin dan Mineral Kopi Sebelum dan Sesudah di Rendam

\begin{tabular}{|l|l|l|l|}
\hline \multirow{2}{*}{ No } & \multirow{2}{*}{ Bahan } & \multicolumn{2}{|c|}{ Kadar (ml/gram) } \\
\cline { 3 - 4 } & & Kopi Beras & Kopi Rendam \\
\hline & Komposisi & & 12,5 \\
2. & Air & 1,21 & 1,28 \\
3. & Kafein & 12,27 & 1,24 \\
4. & Lemak & 8,55 & 14,48 \\
5. & Sula & 18,07 & 0,66 \\
6. & Abu & 3,92 & 10,89 \\
& Kadar Vitamin dan Mineral Penting & & 4,75 \\
1. & Vitamin BI & 0,2 & 0 \\
2. & Vitamin B2 & 0,23 & 0,3 \\
3. & Vitamin B6 & 0,143 & 0,011 \\
4. & Vitamin B12 & 0,00011 & 0,00006 \\
5. & Sodium & 4 & 1,4 \\
6. & Ferrum & 3,7 & 4,7 \\
7. & Flour & 0,45 & 0,24 \\
\hline
\end{tabular}

Sumber : Najiyati (1998:190) 
Dari tabel I-3 dapat dilihat bahwa kopi yang kita konsumsi sehari-hari banyak memiliki kandungan nilai gizi yaitu pada kopi beras mengandung vitamin B1 sebanyak 0,2 gram, vitamin B2 sebanyak 0,23 gram, vitamin B6 sebanyak 0,143 gram, vitamin B 12 sebanyak 0,00011, sodium sebanyak 4 gram, ferrum sebanyak 3,7 gram dan flour 0,45 gram. Dan kandungan gizi pada kopi rendang mengandung vitamin B1 sebanyak 0 gram, vitamin B2 sebanyak 0,3 gram, vitamin B6 sebanyak 0,011 gram, vitamin B 12 sebanyak 0,00006, sodium sebanyak 1,4 gram, ferrum sebanyak 4,7 gram dan flour 0,24 gram.

Menikmati kopi saat ini menjadi hal yang sudah biasa ada di kota-kota besar. Terlebih menikmati kopi di warung kopi yang ada di sekitar pemukiman penduduk maupun yang berada jauh dari pemukiman penduduk. Dengan meningkatnya konsumsi kopi yang ada pada masyarakat dewasa ini berdampak terhadap persaingan warung kopi yang memang menjual kopi untuk memenuhi Tabel I-4 : Jenis-Jenis Olahan Kopi di Warung Kopi One Love Kota Kuala Simpang

\begin{tabular}{|l|l|c|}
\hline No & Minuman & Harga $(\mathrm{Rp})$ \\
\hline 1 & Kopi susu & 9.000 \\
2 & Kopi tubruk & 5.000 \\
3 & Kopi ulee kareng & 5.000 \\
4 & Kopi klasik & 5.000 \\
5 & Aneka Jus & 10.000 \\
\hline
\end{tabular}

Sumber : Warung Kopi One Love, 2014

Dari tabel I-4 dapat dilihat bahwa jenis olahan kopi yang di sediakan di warung kopi One Love yang di sediakan dengan harga yang terjangkau. Jenis kopi yang disediakan antara lain kopi susu, kopi tubruk, kopi ulee kareng, kopi klasik dan aneka jus yang ditawarkan. Ditambah dengan ketersediaan layanan wifi untuk mendukung usaha warung kopi One Love tersebut.

Kepuasan pengunjung merupakan tingkat perasaan seseorang setelah membandingkan kinerja atau hasil yang dirasakan dengan harapannya. Tingkat kepuasan merupakan fungsi dari perbedaan antara kinerja yang dirasakan dengan harapan. Apabila kinerja dibawah harapan, maka pelanggan akan sangat kecewa, namun sebaliknya bila kinerja sesuai harapan, maka pelanggan akan sangat puas.

Kualitas produk merupakan kemampuan suatu produk untuk melaksanakan fungsinya meliputi, daya tahan keandalan, ketepatan kemudahan operasi dan kebaikan serta atribut bernilai lainnya. Untuk meningkatkan kualitas produk suatu usaha dapat menerapkan TQM (Total Quality Manajemen). Selain mengurangi kerusakan produk, tujuan pokok kualitas total adalah untuk meningkatkan nilai konsumen.

Kualitas pelayanan merupakan proses pemenuhan kebutuhan melalui aktifitas orang lain secara langsung. Pelayanan juga dapat diartikan sebagai aktifitas atau hasil yang dapat ditawarkan oleh suatu lembaga kepada pihak lain yang kebutuhan konsumen kopi yang semakin beragam.

Kota Kuala Simpang merupakan salah satu kota yang memiliki tingkat kepadatan penduduk yang tinggi. Jumlah penduduk yang meningkat mengindikasikan adanya peningkatan kebutuhan akan konsumsi pangan termasuk terhadap konsumsi kopi. Meningkatnya konsumsi kopi mengakibatkan berkembangnya usaha warung kopi di Kota Kuala Simpang, salah satunya ialah warung kopi One Love yang akan di jadikan sebagai objek penelitian pada skripsi ini.

Warung kopi One Love merupakan salah satu warung kopi modern yang terletak di jalan Ir. H. Juanda - Terban Kota Kuala Simpang Kabupaten Aceh Tamiang, yang didirikan oleh ibu Ranisa Elvi pada tahun 2010 dengan ide bisnis melalui kegemaran penduduk mengkonsums kopi. Untuk mengetahui Jenis-jenis bahan olahan kopi di warung kopi One Love dapat dilihat pada tabel berikut.

hasilnya tidak kasat mata, dan hasilnya tidak dapat dimiliki oleh pihak lain tersebut.

Lokasi merupakan letak/tempat yang dinyatakan paling tepat untuk melancarkan suatu proses pemasaran yang akan dijalankan seorang pengusaha pada usahanya. Lokasi yang tepat merupakan salah satu faktor pendukung suatu kegiatan usaha untuk mendatangkan konsumen yang lebih ramai untuk menikmati semua produk yang ditawarkan.

Dari penjelasan mengenai warung kopi tersebut penulis tertarik untuk meneliti analisis pengaruh kualitas produk, pelayanan dan lokasi terhadap kepuasan pengunjung warung kopi One Love di Kota Kuala Simpang.

\section{Identifikasi Masalah:}

Berdasarkan judul dan latar belakang yang telah di kemukakan, dapat di identifikasi masalah sebagai berikut : apakah kualitas produk, pelayanan dan lokasi berpengaruh terhadap kepuasan pengunjung warung kopi One Love di Kota Kuala Simpang

\section{Tujuan penelitian :}

Adapun tujuan penelitian ini adalah untuk mengetahui pengaruh kualitas produk, pelayanan dan lokasi terhadap kepuasan pengunjung warung kopi One Love di Kota Kuala Simpang. 
Metode Penelitian

Lokasi, Ruang Lingkup dan Waktu Penelitian L

Penelitian ini dilakukan dengan metode survey. Menurut Nazir (2009:56), Metode survey adalah penyelidikan untuk memperoleh fakta dari gejala-gejala dan mencari keteranganketerangan secara faktual baik tentang institusi sosial, ekonomi atau politik dari suatu kelompok ataupun suatu daerah. Penentuan lokasi penelitian dilakukan di Kota Kuala Simpang Kabupaten Aceh Tamiang, dengan pertimbangan bahwa warung kopi One Love merupakan salah satu warung kopi yang banyak diminati masyarakat untuk mengkonsumsi kopi.

Objek dalam penelitian ini adalah konsumen/pengunjung yang mengkonsumsi kopi di warung kopi One Love Kota Kuala Simpang. Ruang lingkup penelitian meliputi produk, pelayanan, lokasi penjualan warung kopi One Love di Kota Kuala Simpang Kabupaten Aceh Tamiang. Waktu penelitian ini dilaksanakan pada bulan April - Mei 2015.

Populasi dalam penelitian ini adalah semua konsumen yang mengkonsumsi kopi di warung kopi One Love Kota Kuala Simpang. Metode pengambilan sampel yaitu secara sampling kuota. Menurut Sugiyono (2010:122) Sampling kuota adalah teknik untuk menentukan sampel dan populasi yang mempunyai ciri-ciri tertentu sampai jumlah (kuota) yang diinginkan. Berdasarkan metode tersebut jumlah sampel yang diambil dalam penelitian ini adalah sebanyak 33 orang.

\section{Teknik Pengumpulan Data}

Data yang dikumpulkan dalam penelitian ini adalah data primer dan skunder.

- Data primer, diperoleh dari observasi dengan pengamatan langsung terhadap objek yang akan diteliti yaitu pengunjung warung kopi One Love, wawancara langsung dengan pengunjung warung kopi One Love dan memberi quisioner kepada responden dengan memberikan daftar pertanyaan yang telah dipersiapkan.

- Data sekunder, adalah sumber data yang diperoleh dari lembaga-lembaga atau institusi yang terkait data-data lain yang menunjang pada kebutuhan penelitian.

\section{Variabel dan Data yang dianalisis}

Sesuai dengan latar belakang, kerangka pemikiran dan hipotesis yang telah diformulasikan maka dibutuhkan variabel dan data untuk menguji kebenaran hipótesis penelitian ini, yang terdiri dari

a. Kepuasan Pengunjung (Skor)

b. Kualitas Produk

(Y)

c. Pelayanan

(Skor)

(Skor) $\left(X_{2}\right)$

d. Lokasi

(Skor) $\quad\left(\mathrm{X}_{3}\right)$

\section{Konsep Operasional Variabe}

Dari batasan variabel yang diteliti maka dioperasikan variabel sebagai berikut:

AGRISAMUDRA, Jurnal Penelitian Vol.2 No.I Januari-Juni 2015 a. Kepuasan Pengunjung $(\mathrm{Y})$

Kepuasan pengunjung merupakan perasaan ketertarikan yang positif dari setiap pengunjung terhadap usaha yang dilakukan yang dinyatakan dalam satuan skor. Kepuasan pengunjung yang diukur meliputi:

- Kualitas kopi yang ditawarkan

- Cita rasa kopi yang dihasilkan

- Lokasi yang strategis

- pelayanan yang diberikan dalam proses penyajian kopi

- Fasilitas warung kopi

b. Kualitas Produk $\left(X_{1}\right)$

Kualitas produk merupakan suatu mutu dari banyak nya produk yang ditawarkan hingga cita rasa tersendiri yang ditawarkan suatu usaha yang dinyatakan dalam satuan skor. Kualitas Produk yang diukur meliputi :

- Kenikmatan yang berbeda dibandingkan dengan warung lainnya

- Banyak variasi jenis kopinya

- Kopi yang dihasilkan tidak pernah berbeda dari segi rasa

- Kopi memiliki kekentalan yang cocok pada selera pengunjung

- Kopi memiliki kualitas yang tinggi dibandingkan dengan warung lainnya

c. Pelayanan $\left(\mathrm{X}_{2}\right)$

Pelayanan merupakan sikap dari sisi baik dan buruknya suatu usaha dalam menangani para konsumen yang dinyatakan dalam satuan skor. Kualitas Produk yang diukur meliputi :

- Kemampuan dalam mengolah kopi

- Cekatan dalam menangani kebutuhan pesanan pelanggan

- Menghitung yang akurat dalam administrasi pada saat pelanggan membayar

- Memberikan perhatian serius terhadap pelanggan ketika tempat penuh

- Tidak membiarkan pelanggan terlalu lama menunggu saat melakukan pemesanan menu

d. Lokasi $\left(\mathrm{X}_{3}\right)$

Lokasi merupakan salah satu fakktor yang menunjang kesuksesan suatu usaha. Lokasi usaha harus strategis sehingga para calon konsumen dengan mudah mengakses tempat yang akan dituju, yang dinyatakan dalam satuan skor. Lokasi yang diukur meliputi :

- Tempat yang nyaman

- Mudah ditemukan

- Dekorasi warung yang baik

- Fasilitas tambahan yang lengkap

- Fasilitas pelengkap dengan kondisi yang baik

\section{Pengukuran Variabel}

Dalam penelitian ini untuk menentukan skor kepuasan pengunjung, kualitas produk, pelayanan dan lokasi usaha digunakan skala likert dengan lima jenjang. (Sugiyono, 2008 : 133) "Skala Likert yaitu untuk mengukur sikap, pendapat, dan 
persepsi seseorang atau sekelompok orang tentang fenomena sosial". Dengan kriteria pengukurannya sebagai berikut:
1). Setuju
diberi skor
3
3). Netral
(N)
diberi skor
3). Tidak Setuju (TS)
diberi skor

\section{Model Analisis dan Pengujian Hipotesis}

Data dikumpulkan dilapangan diolah dan ditabulasikan menurut kebutuhan analisis. Model yang digunakan untuk pengujian hipotesis dalam penelitian ini adalah dengan menggunakan regresi linier berganda. Menurut Sudjana (2005:347) menjelaskan "Regresi linier berganda adalah untuk mengetahui arah hubungan antara variabel independen dengan variabel dependen berhubungan positif atau negatif dan untuk memprediksi nilai dari variabel dependen apabila nilai variabel independen mengalami kenaikan atau penurunan". persamaannya dapat ditulis sebagai berikut :

$Y=a_{0}+a_{1} X_{1}+a_{2} X_{2}+a_{3} X_{3}+e$

Keterangan :

$\mathrm{Y}=$ Kepuasan Pengunjung (Skor)

$\mathrm{X}_{1}=$ Kualitas produk (Skor)

$\mathrm{X}_{2}=$ Pelayanan

$\mathrm{X}_{3}=$ Lokasi (Skor)

$\mathrm{e}=$ Variabel pengganggu,

ao = konstanta

$a_{1}, a_{2}$ dan $a_{3}=$ Koefisien regresi yang dicari.

Koefisien Determinan $\left(\mathrm{R}^{2}\right)$ bertujuan

untuk mengetahui seberapa besar kemampuan variabel independen menjelaskan variabel terikat. Sudjana (2005:383) menjelaskan "Koefisien determinasi $\left(R^{2}\right)$ adalah keragaman atau variansi total nilai peubah $\mathrm{Y}$ yang dapat dijelaskan oleh nilai peubah $\mathrm{X}$ melalui hubungan linier".

$$
R^{2}=\frac{J K r e g}{\sum y^{2}}
$$

Dimana :

$\mathrm{R}^{2} \quad=$ Koefisien Determinasi ( persentase hubungan $\mathrm{X}_{1}, \mathrm{X}_{2}$ dan $\mathrm{X}_{3}$ terhadap $\mathrm{Y}$ )

$\mathrm{Jk}$ reg $=$ Jumlah Kuadrat Regresi

$\Sigma y^{2} \quad=$ Jumlah Kuadrat Total

Untuk menguji secara serempak pengaruh variabel bebas $\left(X_{1}, X_{2}\right.$, dan $\left.X_{3}\right)$ terhadap variabel terikat $(Y)$, digunakan uji $F$ (Sudjana, 2005:355) menjelaskan "uji $f$ adalah metode pengujian yang dilakukan untuk mengetahui pengaruh variabel bebas secara bersama-sama terhadap variabel terikat". Digunakan rumus sebagai berikut :

$$
F=\frac{J K_{r e g} / k}{J K_{r e s} /(n-k-1)} \ldots . . .(\text { Sudjana, 2005:355) }
$$

Dimana:

$$
\begin{array}{ll}
\mathrm{JK}_{\text {reg }} & =\text { Jumlah kuadrat-kuadrat untuk regresi } \\
\mathrm{K} & =\text { Banyaknya variebel bebas } \\
\mathrm{JK}_{\text {res }} & =\text { Jumlah kuadrat-kuadrat residu } \\
\mathrm{n} & =\text { Jumlah sampel }
\end{array}
$$

Dengan ketentuan :

$\mathrm{F}_{\text {hit }}>\mathrm{F}$ tabel, pada taraf $0,05=95 \%$ dan $0,01=$ 99\%, maka terima Ha tolak Ho

$\mathrm{F}_{\text {hit }}<\mathrm{F}$ tabel, pada taraf $0,05=95 \%$ dan $0,01=$ 99\%, maka tolak Ha terima Ho

Dimana :

$\mathrm{Ha}$ : Kualitas produk, pelayanan dan lokasi secara serempak berpengaruh terhadap kepuasan pengunjung warung kopi One Love di Kota Kuala Simpang

Ho : Kualitas produk, pelayanan dan lokas secara serempak tidak berpengaruh terhadap kepuasan pengunjung warung kopi One Love di Kota Kuala Simpang

Untuk mengetahui pengaruh secara parsial digunakan uji t untuk pengujian. Sudjana, (2005:388) menjelaskan "uji t adalah metode pengujian yang dilakukan untuk mengetahui pengaruh variabel bebas sacara individual terhadap variabel terikat ". Dengan rumus sebagai berikut:

$$
\text { thit }=\frac{a i}{\text { Sai }}
$$
(Sudjana, 2005:388)

Keterangan :

$\begin{array}{lll}\mathrm{t} & =\text { Uji secara terpisah (parsial) } \\ \text { ai } & =\text { Koefisien regresi yang dicari } \\ \text { Sai } & =\text { Standar error dari koefisien }\end{array}$
regresi

Uji parsial (Uji t) bertujuan untuk mengetahui besarnya pengaruh masing-masing variabel independen secara individual (parsial) terhadap variabel dependen.

keputusan:

Dengan ketentuan pengambilan

$t_{\text {hit }}>t_{\text {tabel }}$, pada taraf $0,05=95 \%$ dan $0,01=99 \%$, maka terima $\mathrm{Ha}$ tolak $\mathrm{Ho}$

$t_{\text {hit }}<t_{\text {tabel }}$, pada taraf 0,05 $=95 \%$ dan $0,01=99 \%$, maka tolak Ha terima Ho

$\mathrm{Ha}$ : Kualitas produk, pelayanan dan lokasi secara parsial berpengaruh terhadap kepuasan pengunjung warung kopi One Love di Kota Kuala Simpang

Ho : Kualitas produk, pelayanan dan lokasi secara parsial tidak berpengaruh terhadap kepuasan pengunjung warung kopi One Love di Kota Kuala Simpang

\section{Hasil Penelitian dan Pembahasan}

\section{Karakteristik Pengunjung}

Karakteristik pengunjung dalam penelitian ini meliputi umur, pendidikan, jenis pekerjaan, dan rata-rata penghasilan per bulan. Menurut Rini (2005:26), "mengemukakan karakteristik pengunjung adalah bagian dari pribadi dan melekat pada diri seseorang. Karakteristik ini mendasari tingkah laku seseorang dalam situasi kerja maupun situasi yang lainnya". Karakteristik akan mempengaruhi kepuasan pengunjung. Karakteristik pengunjung pada warung kopi one 
love dengan rata - rata umur pengunjung 29 tahun dan rata - rata pendidikan 14 tahun ini tergolong tergolong tinggi antara SLTA dan Universitas, dengan penghasilan rata-rata $\mathrm{Rp}$. 1.769.697.

\section{Kepuasan Pengunjung $(\mathrm{Y})$}

Kepuasan pengunjung dalam penelitian ini adalah perasaan senang seorang pengunjung karena

Tabel IV-2 Rata-rata Nilai Skor Kepuasan Pengunjung Warung Kopi One love

\begin{tabular}{|c|c|c|c|c|c|}
\hline \multirow{3}{*}{ No } & \multirow{3}{*}{ Pernyataan } & \multicolumn{3}{|c|}{ Jumlah Skor Kepuasan Pengunjung } & \multirow{3}{*}{ Rata-rata } \\
\hline & & (S) & $(\mathrm{R})$ & (TS) & \\
\hline & & 3 & 2 & 1 & \\
\hline 1. & $\begin{array}{l}\text { Kepuasaan pengunjung warung kopi One love ditentukan } \\
\text { oleh kualitas kopi yang ditawarkan }\end{array}$ & 20 & 13 & - & 2,6 \\
\hline 2. & $\begin{array}{l}\text { Kepuasaan pengunjung warung kopi One love ditentukan } \\
\text { oleh cita rasa kopi yang dihasilkan }\end{array}$ & 27 & 6 & - & 2,8 \\
\hline 3. & $\begin{array}{l}\text { Kepuasaan pengunjung warung kopi One love ditentukan } \\
\text { oleh lokasi yang strategis }\end{array}$ & 25 & 8 & - & 2,7 \\
\hline 4. & $\begin{array}{l}\text { Kepuasaan pengunjung warung kopi One love ditentukan } \\
\text { oleh pelayanan yang diberikan dalam proses penyajian kopi }\end{array}$ & 24 & 9 & - & 2,6 \\
\hline 5. & $\begin{array}{l}\text { Kepuasaan pengunjung warung kopi One love ditentukan } \\
\text { oleh fasilitas warung kopi }\end{array}$ & 21 & 12 & - & 2,6 \\
\hline \multicolumn{5}{|c|}{ Rata-rata } & 2,7 \\
\hline
\end{tabular}

Sumber : Data Primer Diolah, 2014

Berdasarkan Tabel IV-2 dapat dilihat bahwa kepuasan pengunjung pada warung kopi one love dengan jumlah kepuasan dari konsumen memiliki hubungan yang kuat atau berpengaruh sesuai dengan skala likert dimana dari 5 pernyataan yang merupakan kepuasan pengunjung terdapat nilai tertinggi dan terendah. Nilai tertinggi skor kepuasan pengunjung dapat dilihat pada pernyataan ke 2 yaitu 27 orang menyatakan setuju, 6 orang ragu-ragu dengan rata-rata skor 2,8 pada pernyataan kepuasaan pengunjung warung kopi One love ditentukan oleh cita rasa kopi yang dihasilkan.

Untuk nilai terendah skor kepuasan pengunjung dapat dilihat pada pernyataan ke 1 yaitu 20 orang menyatakan setuju pada pernyataan kepuasaan pengunjung warung kopi One love ditentukan oleh kualitas kopi yang Tabel IV-3. Rata-rata Nilai Skor Kualitas Produk Warung Kopi One love

\begin{tabular}{|c|c|c|c|c|c|}
\hline \multirow{3}{*}{ No } & \multirow{3}{*}{ Pernyataan } & \multicolumn{3}{|c|}{ Jumlah skor kualitas produk } & \multirow{3}{*}{ Rata-rata } \\
\hline & & \multirow{2}{*}{\begin{tabular}{|l} 
(S) \\
3 \\
\end{tabular}} & \multirow{2}{*}{$\begin{array}{l}(\mathrm{R}) \\
2 \\
\end{array}$} & \multirow{2}{*}{$\frac{(\mathrm{TS})}{1}$} & \\
\hline & & & & & \\
\hline 1. & $\begin{array}{l}\text { Kopi yang dihasilkan oleh warung kopi One love } \\
\text { memiliki kenikmatan yang berbeda dibandingkan } \\
\text { dengan warung lainnya }\end{array}$ & 22 & 11 & - & 2,7 \\
\hline 2. & $\begin{array}{l}\text { Kopi yang dihasilkan oleh warung kopi One love } \\
\text { memiliki banyak variasi jenisnya }\end{array}$ & 22 & 10 & 1 & 2,6 \\
\hline 3. & $\begin{array}{l}\text { Kopi yang dihasilkan oleh warung kopi One love tidak } \\
\text { pernah berbeda dari segi rasa yang dihasilkan }\end{array}$ & 19 & 14 & - & 2,6 \\
\hline 4. & $\begin{array}{l}\text { Kopi yang dihasilkan oleh warung kopi One love } \\
\text { memiliki kekentalan yang cocok pada selera } \\
\text { pengunjung }\end{array}$ & 23 & 10 & - & 2,7 \\
\hline 5. & $\begin{array}{l}\text { Kopi yang dihasilkan oleh warung kopi One love } \\
\text { memiliki kualitas yang tinggi dibandingkan dengan } \\
\text { warung lainnya }\end{array}$ & 20 & 12 & 1 & 2,6 \\
\hline \multicolumn{5}{|c|}{ Rata-rata } & 2,7 \\
\hline
\end{tabular}

Sumber : DATA PRIMER DIOLAH, 2014

Dari tabel IV-3 dapat dilihat skor kualitas produk memiliki nilai yang bervariasi. Skor dalam kualitas produk pada warung kopi one love di Kuala Simpang memiliki nilai skor yang tertinggi dan terendah. Skor tertinggi terdapat mendapatkan hasil yang sesuai dengan harapan pengunjung itu sendiri. Kepuasan yang diteliti dalam penelitian ini dihitung dengan menggunakan skor. Untuk melihat skor hasil pengamatan dari kepuasan pengunjung di warung Kopi One love Kota Kuala Simpang dapat dilihat pada Tabel IV-2 berikut:

\begin{abstract}
ditawarkan dan 13 orang menyatakan ragu-ragu dengan rata-rata 2, 6 skor. Hasil keseluruhan ratarata skor respon konsumen di Kota Kuala Simpang adalah 2,7 itu artinya nilai rata-rata kepuasan pengunjung memiliki nilai skor yang tinggi.
\end{abstract}

\section{Kualitas produk $\left(\mathrm{X}_{1}\right)$}

Kualitas merupakan salah satu faktor yang harus di perhatikan dalam suatu produk. Dengan adanya kualitas produks yang baik akan menyebabkan sebuah usaha semakin maju. Kualitas produk dalam penelitian ini dihitung menggunakan skor. Untuk melihat skor hasil pengamatan dari kualitas produk di warung Kopi One love Kota Kuala Simpang dapat dilihat pada Tabel IV-3 berikut :

AGRISAMUDRA, Jurnal Penelitian Vol.2 No.I Januari-Juni 2015 
Untuk skor terendah terdapat pada pernyataan ke 3 kopi yang dihasilkan oleh warung kopi one love tidak pernah berbeda dari segi rasa yang dihasilkan dan mendapatkan skor 19 mengatakan setuju, dan 14 mengatakan raguragu dengan nilai rata-rata sebesar 2,6 skor. Artinya kepuasan pengunjung warung kopi One Love di Kecamatan Kota Kuala Simpang pada kualitas produk telah mendekati setuju karena memiliki rata-rata nilai skor sebesar 2,7, yang Tabel 1V-4 : Rata-rata Nilai Skor Kualitas Layanan Warung Kopi One Love didukung dengan kenikmatan rasa kopi, variasi kopi, kekentalan kopi, dan kopi kualitas.

\section{Kualitas layanan $\left(\mathrm{X}_{2}\right)$}

Kualitas layanan dalam penelitian ini memiliki skor yang beragam, dengan memiliki nilai tertinggi dan nilai terendah. Untuk mengetahui skor kualitas layanan pada warung kopi one love dalam penelitian ini dapat dilihat pada tabel IV-4 berikut ini :

\begin{tabular}{|c|c|c|c|c|c|}
\hline \multirow{3}{*}{ No } & \multirow{3}{*}{ Pernyataan } & \multicolumn{3}{|c|}{ Jumlah Skor Kualitas Layanan } & \multirow{3}{*}{ Rata-rata } \\
\hline & & $(\mathrm{S})$ & $(\mathrm{R})$ & $(\mathrm{TS})$ & \\
\hline & & 3 & 2 & 1 & \\
\hline 1. & $\begin{array}{lcccc}\text { Karyawan warung kopi } & \text { One } & \text { love } & \text { memiliki } \\
\text { kemampuan dalam mengolah kopi } & & \end{array}$ & 20 & 8 & 5 & 2,5 \\
\hline 2. & $\begin{array}{l}\text { Karyawan warung kopi One love cekatan dalam } \\
\text { menangani kebutuhan pesanan pelanggan }\end{array}$ & 21 & 8 & 4 & 2,5 \\
\hline 3. & $\begin{array}{l}\text { Karyawan warung kopi One love memiliki } \\
\text { kemampuan menghitung yang akurat dalam } \\
\text { administrasi pada saat pelanggan membayar }\end{array}$ & 15 & 15 & 3 & 2,4 \\
\hline 4. & $\begin{array}{l}\text { Karyawan warung kopi One love memberikan } \\
\text { perhatian serius terhadap pelanggan ketika tempat } \\
\text { penuh }\end{array}$ & 22 & 7 & 4 & 2,5 \\
\hline 5. & $\begin{array}{l}\text { Karyawan warung kopi One love tidak membiarkan } \\
\text { pelanggan terlalu lama menunggu saat melakukan } \\
\text { pemesanan menu }\end{array}$ & 22 & 6 & 5 & 2,5 \\
\hline \multicolumn{5}{|c|}{ Rata-rata } & 2,5 \\
\hline
\end{tabular}

Sumber : Data Primer diolah, 2014

Dari tabel IV-4 dapat dilihat skor dari kualitas layanan memiliki nilai yang bervariasi. Skor dalam kualitas layanan pada Warung Kopi One love di Kuala Simpang memiliki nilai skor yang tertinggi dan terendah. Skor tertinggi terdapat pada dua pernyataan yaitu pada pernyataan ke 4 dan 5 karyawan warung kopi one love memberikan perhatian serius kepada pelanggan ketika tempat penuh dengan nilai ratarata skor 2,5 mengatakan setuju skor 7 mengatakan ragu-ragu, dan skor 4 untuk tidak setuju dan karyawan warung kopi One love tidak membiarkan pelanggan terlalu lama menunggu saat melakukan pemesanan menu dengan nilai rata-rata skor 2,5 mengatakan setuju skor 6 mengatakan ragu-ragu, dan skor 5 untuk tidak setuju.

Untuk skor terendah terdapat pada pernyataan ke 3 Karyawan warung kopi One love memiliki kemampuan menghitung yang akurat dalam administrasi pada saat pelanggan membayar dan mendapatkan skor 15 untuk Tabel IV-5 . Rata-rata Nilai Skor Lokasi Warung Kopi One love

\begin{tabular}{|c|c|c|c|c|c|}
\hline \multirow{3}{*}{ No } & \multirow{3}{*}{ Pernyataan } & \multicolumn{3}{|c|}{ pengunjung } & \multirow{3}{*}{ Rata-rata } \\
\hline & & (S) & $(\mathrm{R})$ & (TS) & \\
\hline & & 3 & 2 & 1 & \\
\hline 1. & Warung kopi One love memiliki tempat yang nyaman & 22 & 11 & - & 2,7 \\
\hline 2. & Warung kopi One love mudah untuk ditemukan & 26 & 7 & - & 2,8 \\
\hline 3. & $\begin{array}{l}\text { Warung kopi One love memiliki dekorasi yang } \\
\text { menarik }\end{array}$ & 22 & 9 & 2 & 2,6 \\
\hline 4. & $\begin{array}{l}\text { Warung kopi One love memiliki fasilitas tambahan } \\
\text { yang lengkap seperti wifi gratis untuk pengunjung }\end{array}$ & 27 & 4 & 2 & 2,8 \\
\hline 5. & $\begin{array}{l}\text { Warung kopi One love memiliki fasilitas pelengkap } \\
\text { dalam kondisi yang baik dengan tersedianya wifi, } \\
\text { televisi, tempat parkir, dan lain-lain }\end{array}$ & 23 & 7 & 3 & 2,6 \\
\hline Rat & & & & & 2,7 \\
\hline
\end{tabular}

Sumber : Data Primer Diolah, 2014 setuju, skor 15 untuk ragu-ragu dan 3 untuk tidak setuju dengan nilai rata-rata sebesar 2,4 skor. Artinya kepuasan pengunjung warung kopi One Love di Kecamatan Kota Kuala Simpang pada kualitas layanan berada antara netral dan setuju karena memiliki rata-rata nilai skor sebesar 2,5, yang didukung dengan kemampuan pengolahan kopi, penanganan kebutuhan konsumen, penghitungan yang akurat, perhatian yang serius terhadap pengunjung ketika tempat penuh dan tidak membiarkan pengunjung menunggu pesanan terlalu lama.

\section{Lokasi $\left(X_{3}\right)$}

Lokasi yang strategis juga menjadi salah satu faktor kemajuan suatu usaha. Lokasi warung kopi One Love dalam penelitian ini dihitung dengan menggunakan skor. Untuk lebih jelasnya mengenai skor dari lokasi di daerah penelitian dapat dilihat pada tabel IV-5 berikut ini :

AGRISAMUDRA, Jurnal Penelitian Vol.2 No.I Januari - Juni 2015 
Dari tabel IV-5 dapat dilihat skor lokasi warung kopi one love memiliki nilai yang bervariasi. Skor lokasi warung kopi one love di kuala simpang memiliki nilai skor yang tertinggi dan terendah. Skor tertinggi terdapat pada pernyataan ke 4 Warung kopi One love memiliki fasilitas tambahan yang lengkap seperti wifi gratis untuk pengunjung dengan skor 27 untuk setuju, skor 4 untuk ragu-ragu,dan skor 2 untuk tidak setuju dengan nilai rata-rata 2,8 skor.

Untuk skor terendah terdapat pada pernyataan ke 3 Warung kopi One love memiliki dekorasi yang menarik dan mendapatkan skor 22 untuk setuju, skor 9 untuk ragu-ragu dan skor 2 untuk tidak setuju dengan nilai rata-rata yang didapat sebesar 2,6 skor. Artinya kepuasan pengunjung warung kopi One Love di Kecamatan Kota Kuala Simpang pada lokasi telah mendekati setuju karena memiliki rata-rata nilai skor sebesar 2,7 , yang didukung dengan tempat yang nyaman, mudah ditemukan, dekorasi yang menarik, fasilitas pendukung dan fasilitas pendukung yang baik.

\section{Analisis Pengaruh Kualitas Produk, Pelayanan dan Lokasi Terhadap Kepuasan Pengunjung Warung Kopi One love di Kota Kuala Simpang}

Kualitas produk, kualitas pelayanan, dan lokasi berpengaruh terhadap kepuasan pengunjung pada warung kopi one love yang berada di Kota Kuala Simpang. Untuk mengetahui besarnya pengaruh tersebut, maka dianalisis dengan menggunakan regresi linier berganda dan hasil analisis diperoleh persamaan sebagai berikut :

$$
Y=1,57+0,44 X_{1}+0,42 X_{2}+0,19 X_{3}
$$

Dari persamaan tersebut dapat disimpulkan bahwa :

a. Jika kualitas pelayanan dan lokasi dianggap tetap maka setiap penambahan 1 skor kualitas produk akan meningkatkan kepuasan pengunjung warung kopi one love sebesar

Tabel IV-6. Uji Secara Serempak (Uji F) Pengunjung Warung Kopi One Love di Kota Kuala Simpang.

\begin{tabular}{|l|l|l|l|l|l|}
\hline \multirow{2}{*}{ Variabel } & \multirow{2}{*}{ F cari } & \multicolumn{3}{|c|}{ F Tabel } & \multicolumn{3}{|l|}{ Kesimpulan } \\
\cline { 3 - 6 } & $\alpha=0,05$ & $\alpha=0,01$ & $\alpha=0,05$ & $\alpha=0,01$ \\
\hline $\begin{array}{l}\text { - Kualitas produk }\left(X_{1}\right) \\
\text {-Kualitas layanan }\left(X_{2}\right) \\
\text { - Lokasi }\left(X_{3}\right)\end{array}$ & $1.010,66$ & 1,97 & 4,59 & $\begin{array}{l}\text { Fcari > F } \\
\text { Tabel }\end{array}$ & Fcari > FTabel \\
\hline
\end{tabular}

Sumber : Data Primer 2014 (diolah)

Berdasarkan Tabel IV-6 hasil pengujian secara serempak (Uji F) diperoleh $F_{\text {cari }}=1.010,66$ $>\mathrm{F}_{\text {Tabel }}=1,97$ pada tingkat kepercayaan $95 \%(\alpha=$ $0,05)$ dan juga $F_{\text {cari }}=1.010,66>F_{\text {Tabel }}=4,59$ pada tingkat kepercayaan $99 \%(\alpha=0,01)$, sehingga dapat diambil kesimpulan bahwa secara serempak atau bersama-sama variabel kualitas produk $\left(X_{1}\right)$, kualitas layanan $\left(X_{2}\right)$ dan lokasi $\left(X_{3}\right)$ secara keseluruhan memberi pengaruh yang sangat nyata terhadap kepuasan pengunjung warung kopi one love di Kota Kuala Simpang.
0,44 skor. Karena semakin baik kualitas pelayanan dan lokasi maka kepuasan pengunjung terhadap warung kopi one love akan menyebabkan peningkatan pengunjung.

b. Jika kualitas produk dan lokasi dianggap tetap maka setiap penambahan 1 skor kualitas pelayanan akan meningkatkan kepuasan pengunjung warung kopi one love sebesar 0,42 skor. Karena semakin baik kualitas produk dan lokasi maka kepuasan pengunjung terhadap warung kopi one love akan menyebabkan meningkatnya jumlah pengunjung.

c. Jika kulaitas produk dan kualitas pelayanan dianggap tetap maka setiap penambahan 1 skor lokasi akan meningkatkan kepuasan pengunjung warung kopi one love sebesar 0,19 skor. Karena semakin baik kualitas produk dan kualitas pelayanan maka kepuasan pengunjung terhadap warung kopi one love akan menyebabkan meningkatnya jumlah pengunjung.

Dari penilaian diperoleh hasil nilai koefisien determinansi $\left(R^{2}\right)$ sebesar 0,99 atau 99\% artinya analisis kepuasan pengunjung warung kopi One love dipengaruhi oleh kualitas produk $\left(X_{1}\right)$, kualitas layanan $\left(X_{2}\right)$ dan lokasi $\left(X_{3}\right) d i$ Kota Kuala Simpang. Sedangkan $1 \%$ lagi dipengaruhi oleh faktor-faktor lain diluar variabel penelitian yang tidak dihitung nilainya. Untuk lebih jelasnya dapat dilihat pada lampiran 10.

Untuk mengetahui besarnya pengaruh kualitas produk $\left(X_{1}\right)$, kualitas layanan $\left(X_{2}\right)$ dan lokasi $\left(X_{3}\right)$ terhadap kepuasan pengunjung $(Y)$ secara serempak di uji dengan menggunakan uji $\mathrm{F}$, dengan tingkat kepercayaan 95\% $(\alpha=0,05)$ dan 99\% $(\alpha=0,01)$ dengan $\mathrm{db}$ (derajat bebas $)=$ (k,n-k-1), dimana $k$ adalah jumlah variabel bebas dan $\mathrm{n}$ adalah jumlah data atau banyaknya sampel yang diteliti dengan hasilnya seperti tertera pada Tabel IV-6 di bawah ini: 
Tabel IV-7. Uji Secara Parsial (uji t) Pengunjung Warung Kopi One Love di Kota Kuala Simpang.

\begin{tabular}{|c|c|c|c|c|c|}
\hline \multirow{2}{*}{ Variabel } & \multirow{2}{*}{ t cari } & \multicolumn{2}{|l|}{ t Tabel } & \multicolumn{2}{|c|}{ Kesimpulan } \\
\hline & & $\alpha=0,05$ & $\alpha=0,01$ & $\alpha=0,05$ & $\alpha=0,01$ \\
\hline $\begin{array}{l}- \text { Kualitas Produk }\left(\mathrm{X}_{1}\right) \\
\text {-Kualitas Layanan }\left(\mathrm{X}_{2}\right) \\
\text {-Lokasi }\left(\mathrm{X}_{3}\right)\end{array}$ & $\begin{array}{l}24,46 \\
1,35 \\
6,58\end{array}$ & 1,6991 & 2,4620 & $\begin{array}{l}\mathrm{t}_{1} \text { cari }> \\
\text { tabel } \\
\mathrm{t}_{2} \text { cari }< \\
\text { tabel } \\
\mathrm{t}_{3} \text { cari }> \\
\text { tabel }\end{array}$ & $\begin{array}{l}\mathrm{t}_{1} \text { cari }>\text { t Tabel } \\
\mathrm{t}_{2} \text { cari }<\mathrm{t} \text { Tabel } \\
\mathrm{t}_{3} \text { cari }>\text { t Tabel }\end{array}$ \\
\hline
\end{tabular}

Sumber : Data Primer diolah, 2014

Berdasarkan Tabel IV-7 hasil pengujian secara parsial atau secara terpisah pada tingkat kepercayaan 95\% $(\alpha=0,05)$ untuk variabel kualitas produk $\left(X_{1}\right)$, kualitas layanan $\left(X_{2}\right)$ dan lokasi $\left(X_{3}\right)$ dapat dilihat bahwa $\mathrm{t}_{1}$ cari $=24,46$, dan t3cari $=$ $6,55>t_{\text {tabel }}=1,6991$ pada tingkat kepercayaan $95 \%(\alpha=0,05)$ dan $>$ tabel $=2,4620$ pada tingkat kepercayaan $99 \%(\alpha=0,01)$. t2 cari $=1,35<$ tabel $=$ 1,6991 pada tingkat kepercayaan $95 \%(\alpha=0,05)$ dan $<$ tabel $=2,4620$ pada tingkat kepercayaan $99 \%$ $(\alpha=0,01)$. Sehingga diambil kesimpulan bahwa secara terpisah variabel kualitas produk $\left(X_{1}\right)$ dan lokasi $\left(X_{3}\right)$ secara keseluruhan memberi pengaruh yang sangat nyata terhadap kepuasan pengunjung warung kopi one love, sedangkan kualitas layanan $\left(\mathrm{X}_{2}\right)$ tidak memberi pengaruh nyata terhadap kepuasan pengunjung warung kopi one love di Kota Kuala Simpang.

\section{KESIMPULAN DAN SARAN}

\section{Kesimpulan}

Dari hasil penelitian dan pembahasan yang diperoleh dapat diambil sebuah kesimpulan yaitu:

1. Rata-rata pengunjung di warung kopi one love berumur 29 tahun dengan pendidikan ratarata 14 tahun, dan penghasilan rata-rata sebesar Rp. 1.769.697,--.

2. Berdasarkan hasil perhitungan analisis regresi linear berganda maka diperoleh persamaan regresi sebagai berikut : $Y=1,57$ $+0,44 X_{1}+0,42 X_{2}+0,19 X_{3}$.

3. Dari hasil perhitungan diperoleh $\left(R^{2}\right)$ sebesar 0,99 atau $99 \%$ artinya analisis kepuasan pengunjung warung kopi One love dipengaruhi oleh kualitas produk $\left(X_{1}\right)$, kualitas layanan $\left(X_{2}\right)$ dan lokasi $\left(X_{3}\right)$ di Kota Kuala Simpang. Sedangkan $1 \%$ lagi dipengaruhi oleh faktorfaktor lain diluar variabel penelitian yang tidak dihitung nilainya.

4. Hasil pengujian secara serempak (Uji F), dapat diambil kesimpulan bahwa secara serempak atau bersama-sama variabel kualitas produk $\left(X_{1}\right)$, kualitas layanan $\left(X_{2}\right)$ dan lokasi $\left(X_{3}\right)$ secara keseluruhan memberi pengaruh yang sangat nyata terhadap kepuasan pengunjung warung kopi one love di Kota Kuala Simpang.
5. Hasil pengujian secara parsial atau secara terpisah untuk variabel kualitas produk $\left(X_{1}\right)$, kualitas layanan $\left(\mathrm{X}_{2}\right)$ dan lokasi $\left(\mathrm{X}_{3}\right)$ dapat diambil kesimpulan bahwa secara terpisah variabel kualitas produk $\left(X_{1}\right)$, kualitas layanan $\left(X_{2}\right)$ dan lokasi $\left(X_{3}\right)$ secara keseluruhan memberi pengaruh yang sangat nyata terhadap kepuasan pengunjung warung kopi one love di Kota Kuala Simpang.

\section{Saran}

1. Warung kopi one love diharapkan lebih meningkatkan kualitasnya baik dari produk maupun pelayanannya supaya lebih baik lagi kedepannya

2. Persaingan antara warung kopi membuat pengusaha warung kopi one love untuk menyediakan pelayanan yang terbaik

3. Perlu adanya fasilitas yang nyaman untuk dinikmati pengunjung, seperti pelayanan karyawan terhadap pengunjung yang lebih baik lagi, mempertahankan cita rasa kopi yang berbeda dengan warung lainnya kepada pengunjung dan mengutamakan pelayanan pengunjung agar tetap menjadi pelanggan

4. Karena Warung kopi one love letaknya berada di pusat Kota Kuala Simpang, demi kenyamanan pengunjung diharakan warung kopi one love menyediakan tempat parkir kendaraan yang memadai sehingga pengunjung merasa nyaman.

\section{DAFTAR PUSTAKA}

Anonimous, 2015. Kecamatan Kota Kuala Simpang Dalam Angka 2014. Kabupaten Aceh Tamiang.

Anonimous, 2007. Peningkatan Konsumsi Kopi dalam Negeri Indonesia Tahun 20022006. Direktorat Jendral Perkebunan, Jakarta

http://pustakabahankuliah.blogspot.com/2013/05 $\angle$ pengertian-dan-definisikepuasan 8.html?m=1 (diakses tanggal 26 November 2014) jam 15:30 WIB. 
Kotler, Philip. 2002. Manajemen Pemasaran di Indonesia : Analisis Perencanaan, Implementasi dan Pengendalian. Salemba 4. Jakarta

Najiati, Sri. 1998. Kopi Budidaya dan Penanganan Lepas Panen, Penebar Swadaya. Jakarta.

Nazir, Mohammad 2009. Metode Penelitian, Edisi Ketujuh, Ghalia Indonesia.

Plantamor.com.budidayakopi (diakses tanggal 27 November 2014) jam 12:30 WIB.

Rini Sri Dami Hartini. 2005.Jurnal Penyuluhan, Volume I, No. I, September 2005.
Stanley, I. 2009. Analisis Kepuasan dan Loyalitas Konsumen Coffeshop Warung Kopi serta Implikasinya Terhadap Strategi Pemasaran. Skripsi Fakultas Pertanian IPB. Bogor.

Sudjana. 2005. Teknik Analisa Regresi dan Korelasi. Tarsito Bandung.

Sugiyono, 2008. Metode Penelitian Kuantitatif Kualitatif $R$ dan $D$, Alfabeta, Bandung.

Tjiptono, Fandy. 2008, Strategi Pemasaran, ANDI, Yogyakarta. 